\title{
NEW SPECIES OF PYGOCEPHALOMORPHA (CRUSTACEA) FROM THE IRATI FORMATION, PARANÁ BASIN, RS, SOUTHERN BRAZIL
}

\author{
KAREN ADAMI-RODRIGUES, PAULA GIOVANA PAZINATO \\ Núcleo de Estudos em Paleontologia e Estratigrafia, UFPel, Praça Domingos Rodrigues, 02, 96010-440, \\ Pelotas, RS, Brazil.karen.adami@gmail.com,pazinata@gmail.com \\ $\dagger$ †RAJÁ DAMIANI PINTO \\ Departamento de Paleontologia e Estratigrafia, UFRGS, Cx. P. 15001, 91540-970, Porto Alegre, RS, Brazil.
}

\begin{abstract}
This paper presents three new genera and species of pygocephalomorph crustaceans from outcrops in Pantano Grande and Minas do Leão counties, State of Rio Grande do Sul, Southern Brazil. The silty shales present molds of mostly articulated crustaceans, in association with Glossopteris, insect remains and fish scales. These new genera expand the number of Pygocephalomorpha from the Irati Formation and contribute to the knowledge on the Gondwanan Malacostraca species.
\end{abstract}

Key words: Paleozoic, crustaceans, Malacostraca, taxonomy, Paraná Basin, Gondwana.

RESUMO - Este trabalho apresenta três novos gêneros e espécies de crustáceo pigocefalomorfo provenientes de afloramentos localizados nos municípios de Pantano Grande e Minas do Leão, Estado do Rio Grande do Sul, sul do Brasil. Os folhelhos síticos apresentam moldes de crustáceos, principalmente articulados, em associação com Glossopteris, restos de insetos e escamas de peixe. Os novos táxons aumentam o número de Pygocephalomorpha da Formação Irati e contribuem para o conhecimento das espécies de Malacostraca do Gondwana.

Palavras-chave: Paleozoico, crustáceos, Malacostraca, taxonomia, Bacia do Paraná, Gondwana.

\section{INTRODUCTION}

Pygocephalomorph crustaceans have been known since the second half of the 19th century from the Carboniferous of England and Scotland (Huxley, 1857; Salter, 1861, 1863; Prestwich, 1840; Peach, 1883). During the 20th century, records were found in the Carboniferous and Permian of the United States of America (Brooks, 1962; Schram, 1988; Hotton et al., 2002; Irham et al., 2010) and South Africa (Rogers \& Du Toit, 1909; Broom, 1931; Fabre \& Huard, 1967); and in the Permian of Russia (Schram, 1978), China (Taylor et al., 1998), South America (Clarke, 1920; Beurlen, 1931, 1934, 1953; Mezzalira, 1954; Vieira et al., 1991; Piñeiro et al., 2012a), and most recently Italy (Jones et al., 2015).

This fossil order presents Eumalacostraca basal characters such as tagmosis of the body into a cephalothorax and pleon, thoracic biramous appendages with only one segment in the protopod, and a carapace completely covering the cephalothorax (Brooks, 1969). Schram (1974) defined Pygocephalomorpha as crustaceans possessing a carapace with branchiostegal development; a pleon equal in length to the thorax or reduced; oöstegites in females; and welldeveloped caudal spines and furca. When proposing the taxon Pygocephalomorpha, Beurlen (1930) questioned its systematic position, since its representatives share characters with both recent Mysida (Peracarida) and Decapoda
(Eucarida). The cephalothorax is mysid-like, with eight sternites and biramous appendages, the first pair being modified into maxillipeds in many species. In addition, the females bear oöstegites - modified epipodites that hold a brood pouch, or marsupium, where the eggs develop until reaching juvenile stage.

The pleon is decapod-like, with a length and width sub-equal to or greater than the cephalothorax, a developed pleomere, large biramous uropods, and a telson bearing a terminal spine (furca). The cephalothorax morphology (Schram, 1984) and phylogenetic analysis (Taylor et al., 1998) indicate that Pygocephalomorpha is a fossil suborder of Mysida, which are benthic crustaceans (Schram, 1986).

The systematic position of Pygocephalomorpha is based mostly on Laurasian taxa, since Gondwanan species are described from sparse and incomplete material, many of them being established on the basis of fragmentary pieces of crustacean fossils (Pinto \& Adami-Rodrigues, 1996), leading to misinterpretations.

Traditionally, three genera and six species are recognized from Brazil: Paulocaris pachecoi Clarke, 1920; P. marianoi Beurlen, 1953; Liocaris huenei Beurlen, 1931; L. angusta Beurlen, 1931; Pygaspis brasiliensis Beurlen, 1934 and P. quadrata Beurlen, 1934, which is currently under revision (Adami-Rodrigues \& Pazinato, pers. comm.). The Brazilian forms are from the Irati Formation (Artinskian/Kungurian) of 
the Paraná Basin, known for oil shales and mesosaurid fossils (Holz et al., 2010).

Pygocephalomorphs occur throughout the whole geographic range of the Irati Formation, from the Center to Southern Brazil, Goiás (Vieira et al., 1991), São Paulo (Clarke, 1920; Beurlen, 1931; Mezzalira, 1954), Paraná (Mezzalira, 1954), Santa Catarina (Beurlen, 1934; Pinto, 1971), and Rio Grande do Sul states (Beurlen, 1953; Pinto, 1955; AdamiRodrigues \& Pinto, 2000). They are also found in Uruguay, from the Mangrullo Formation, Paraná Basin, the stratigraphic equivalent of the Irati Formation (Piñeiro et al., 2012a).

This paper describes three new genera and species of Pygocephalomorpha from the Irati Formation, from State of Rio Grande do Sul (RS), Southern Brazil. The new occurrences of crustaceans presented in this paper extend the record of pygocephalomorphs in the Paraná Basin and contributes to understanding the distribution and diversity of the taxon in Gondwana.

\section{GEOLOGICAL SETTING}

The fossils were collected from three outcrops in Minas do Leão and Pantano Grande counties, RS, Brazil (Figure 1). Outcrop I is a road-cut on the BR-290 (Porto AlegreUruguaiana way), Minas do Leão County, about $2 \mathrm{~km}$ west of Capão da Roça creek. The outcrop is about $90 \mathrm{~m}$ long and $6 \mathrm{~m}$ high, and at its base there is $20 \mathrm{~cm}$ of beige silty shale, green when wet, containing two of the crustaceans here described (Permocaris and Iraticaris), plants, insects, and fish scales. Overlying this bed there is $10 \mathrm{~cm}$ of non-fossiliferous reddish mudstone, which is followed by another layer with 20 $\mathrm{cm}$ of beige silty shale, bearing the same fossils as found in the basal one. Above the siltic shale, there is $1 \mathrm{~m}$ of reddish mudstone, covered by $1.5 \mathrm{~m}$ of fine sandstones with smallsized cross-bedding. The stratigraphic column ends with $3 \mathrm{~m}$ of soil (Figure 2). The locality from which the fossils were collected is currently covered by rubble deposited by Pantano Grande City Hall.

Pinto (1955) discovered this outcrop and described it as the first Palermo Formation (Upper Carboniferous) outcrop in RS. At that time, the few crustacean fossils found led the author to classify them as basal pygocephalomorphs. Later, Pinto (1972) concluded that the fossils were actually new species and the outcrop belonged to the Irati Formation.

Outcrops II and III are small-sized exposures (Figure 3). They are on either side of BR-290, at old Rio Pardo road, about $1.5 \mathrm{~km}$ from Pantano Grande County and $2 \mathrm{~km}$ apart from each other. Outcrop II is $1.5 \mathrm{~km}$ south of BR-290 and at its base there are siltic shales with slump structures, which are followed by gray siltic shales interbedded with yellowish limestone lenses where crustaceans (Pittinucaris) and fish scales are found. According to Figueiredo (1972), in state of Rio Grande do Sul, the Palermo and Irati formations have a gradational contact. Figueiredo (1972) described the Palermo Formation as having beds mostly disturbed by slumping, while the Irati Formation has, in its basal portion, yellowish

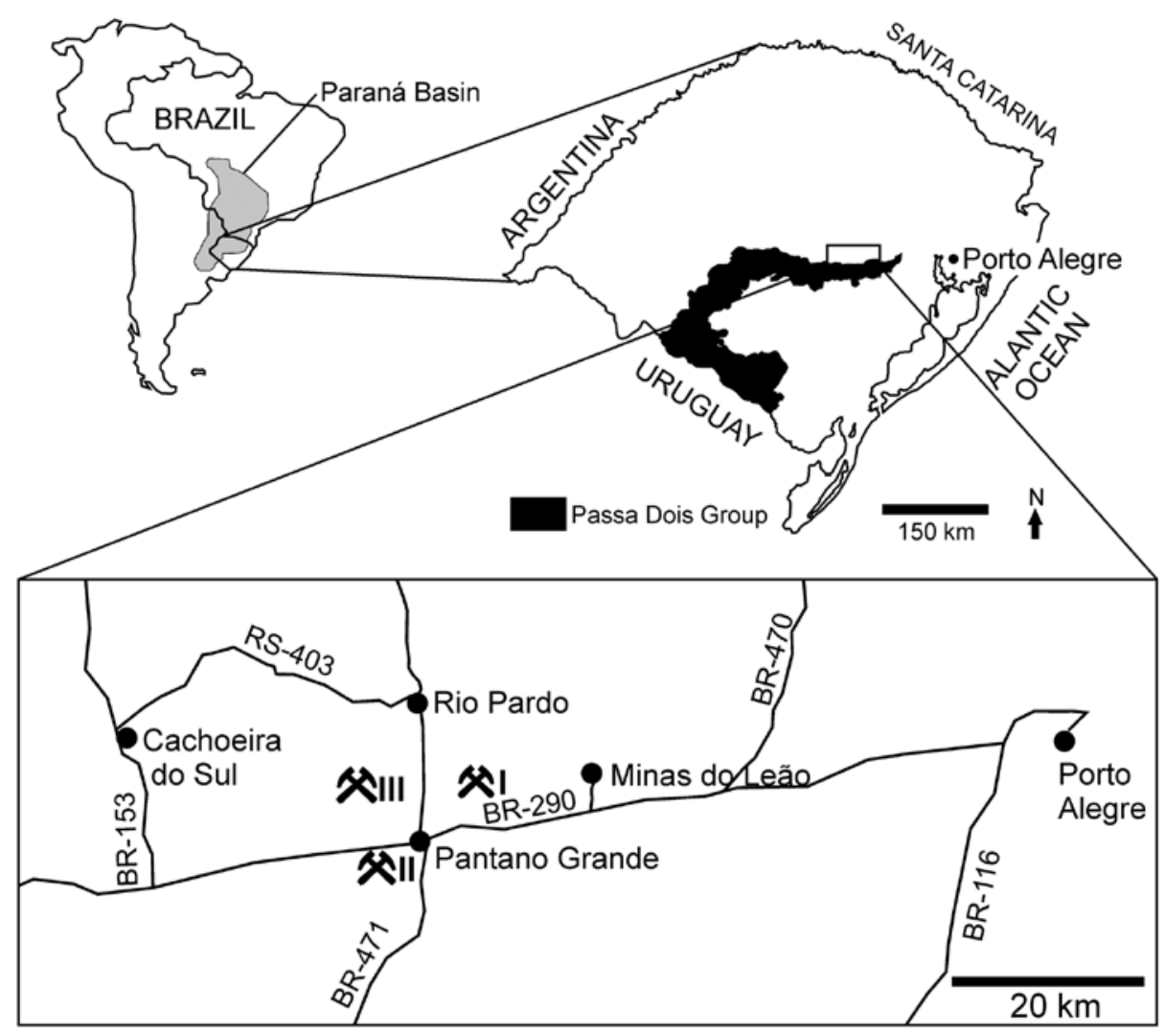

Figure 1. Map of State of Rio Grande do Sul highlighing Minas do Leão and Pantano Grande counties. Geological hammers mark the locations of outcrops I, II and III. 

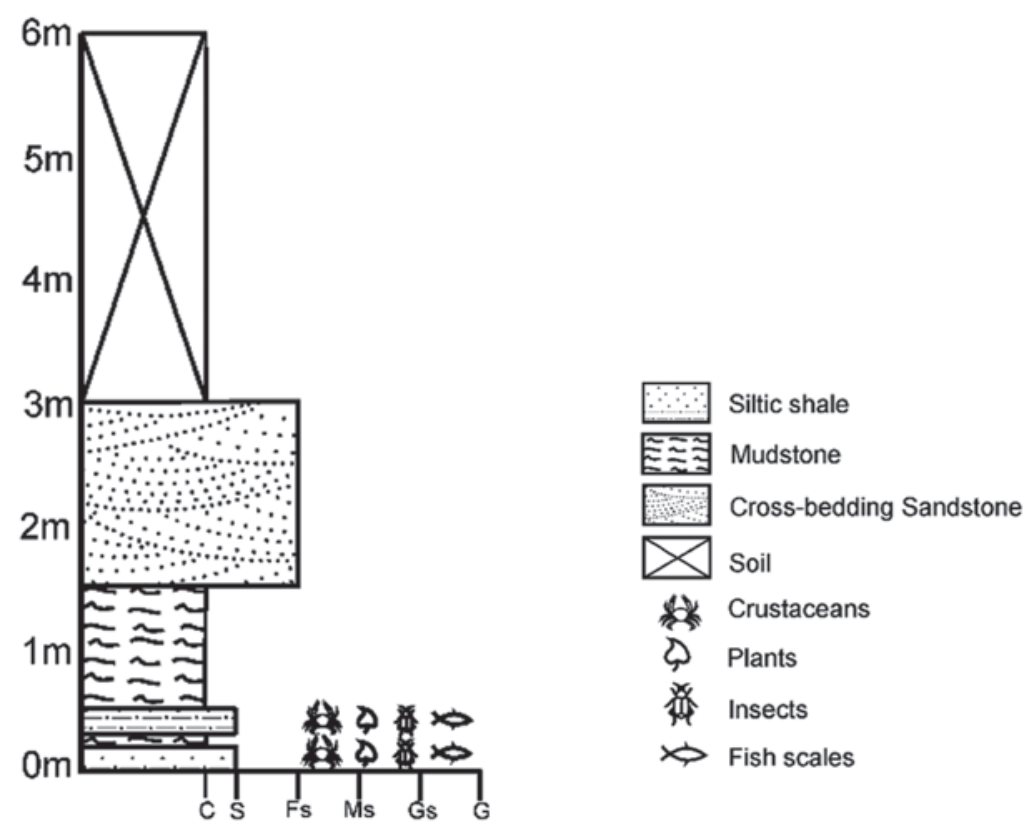

Figure 2. Stratigraphic column of outcrop I, Minas do Leão County, RS. Two of the crustacean species (Permocaris and Iraticaris) are found in the silty shale beds, along with plants, insects, and fish scales. Adapted from Adami-Rodrigues (1998).

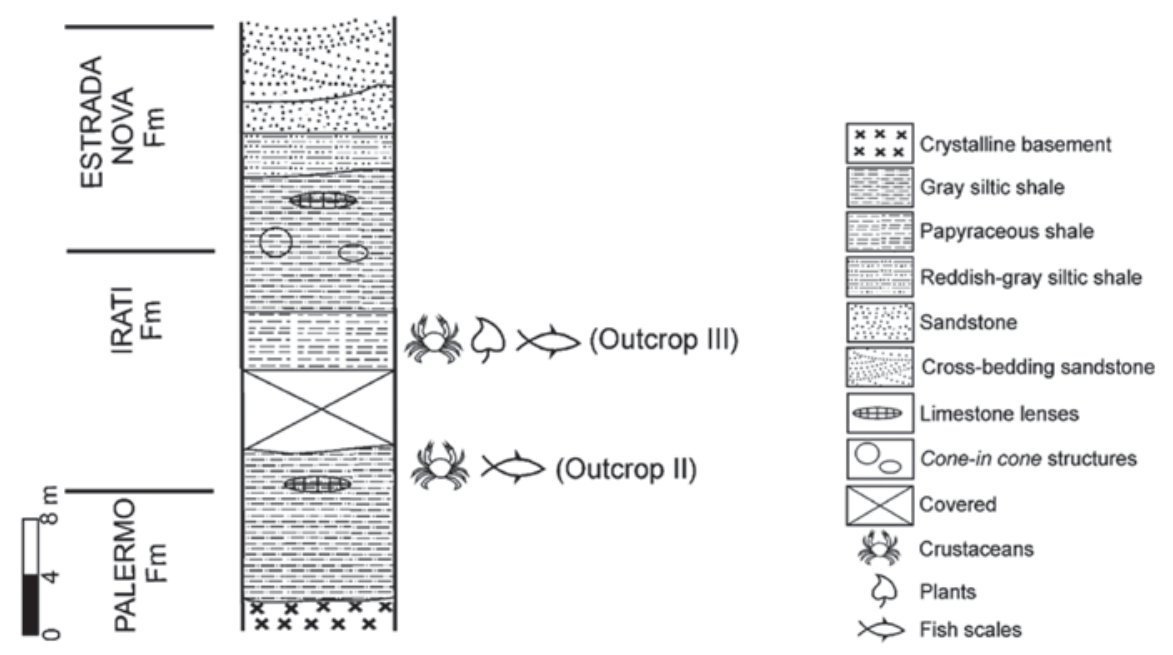

Figure 3. Stratigraphic column from the Pantano Grande area according to Figueiredo (1972), indicating stratigraphic position of outcrops II and III. Adapted from Adami-Rodrigues (1998).

limestone lenses, and alternations of thin layers of light and dark thin siltic shales. Based on this interpretation, the authors consider this outcrop as belonging to the basal portion of the Irati Formation in State of Rio Grande do Sul.

Outcrop III is $4 \mathrm{~km}$ north of BR-290 and exhibits about $4 \mathrm{~m}$ of rock succession comprising brown paper-like shales. The fossils include one species of crustacean (Iraticaris), Glossopteris, and fish scales. The paper-like shales are followed by silty shales with cone-in-cone structures. The lithology and fossils recorded in outcrop III were correlated with the Irati Formation through borehole 180 of the DACM for State of Rio Grande do Sul (Machado \& Castanho, 1956; Figueiredo, 1972).

\section{RESULTS}

The fossils comprise several crustaceans, most of them articulated and a few semi-articulated. In the semi-articulated specimens, the cephalothorax-pleon or the cephalothoraxappendage joints were broken. The crustaceans are preserved as molds, mostly presenting ventral views, possibly in the death position. However, a few isolated remains show dorsal views, such as carapaces and pleons. Pittinucaris fossils are the only ones that show signs of compression. At outcrop I, we collected blocks with dispersed crustaceans (Permocaris and Iraticaris), but that were far more abundant than specimens collected at outcrops II (Pittinucaris) and III (Iraticaris). The 
holotypes are ventral view molds of complete specimens. There is no record of sexual characters in any of the fossils. The species here described correspond to the specimens figured in Adami-Rodrigues (1998), and the generic names given there were retained, except for Pittinucaris, referred in that work to Minicaris; in Adami-Rodrigues \& Pinto (2000), Permocaris was figured as genus A, Iraticaris as genus B, and Pittinucaris as genus C.

Reviews by Pinto (1971) and Pinto \& Adami-Rodrigues (1996) demonstrated that the families created by Brooks (1962) for Pygocephalomorpha cannot be used for classification, as the author had overlapped characters. Because of that, we avoid positioning the new genera and species into families until a review is properly carried out.

The studied specimens are held in the following repository: Museu de Paleontologia, Universidade Federal do Rio Grande do Sul (UFRGS/MP-I), Porto Alegre, Rio Grande do Sul, Brazil. Catalog numbers: MP-I-6613 to MP-I-6646.

\section{SYSTEMATIC PALEONTOLOGY}

Class MALACOSTRACA Latreille, 1802

Subclass EUMALACOSTRACA Grobben, 1892

Superorder PERACARIDA Calman, 1904

Order PYGOCEPHALOMORPHA Beurlen, 1930

Permocaris gen. nov.

Type species. Permocaris purperae sp. nov.

Etymology. Permian crustacean.

Diagnosis. As for the species.

\section{Permocaris purperae sp. nov.}

(Figures 4-5)
Etymology. In honor of Dra. Ivone Purper.

Holotype. UFRGS/MP-I-6643.

Horizon and locality. Outcrop I, km 90 of the BR-290 (Porto Alegre-Uruguaiana way), Minas do Leão County, Rio Grande do Sul, Brazil; lower Permian, Irati Formation.

Diagnosis. Sub-hexagonal carapace, length of the carapace twice as long as its anterior margin; anterior third of carapace almost as large as its length; anterior margin straight, twice the length of the concave posterior margin; carapace without anterolateral nor lateral spines; short triangular rostrum with lateral ridges; eight sub-trapezoidal sternites; eight pairs of thoracic appendages with fused exopod, the first pair chelate; pleon ventrally inflected and about half the length of cephalothorax.

Description. The carapace has a kite-like shape being 8.5 $\mathrm{mm}$ in length from the base of the rostrum. The rostrum has the shape of an equilateral triangle $1.2 \mathrm{~mm}$ high. Lateral ridges extend from the apex of the rostrum until the second third of the cervical groove. The distinctive cervical groove has a goblet shape limited to the mid-anterior portion of the carapace. The anterior margin is straight, truncated, with no spines, and is $37.5 \mathrm{~mm}$ in length, almost twice as long as the posterior margin, which is concave and $1.7 \mathrm{~mm}$ long. Eight cephalothoracic sternites are visible, the first one being sub-triangular and a lot smaller than the following. From the first sternite a long triangular process extends reaching to the sixth sternite, the sternal process, covering the entire first sternite and tapering towards the following one, ending in a wedge at the anterior portion of the sixth sternite. The following sternites are trapezoidal, of similar width, and increasing in height $\left(1^{\circ}\right.$ and $2^{\circ}$ sternites, $1.0 \mathrm{~mm}$ and $1.5 \mathrm{~mm}$, respectively and the following $2.25 \mathrm{~mm}$ ). On each sternite a pair of biramous appendages is jointed. The pleon is ventrally inflected under the thorax resulting in a round-shaped structure $3.8 \mathrm{~mm}$ in length, almost half that of the cephalothorax. There
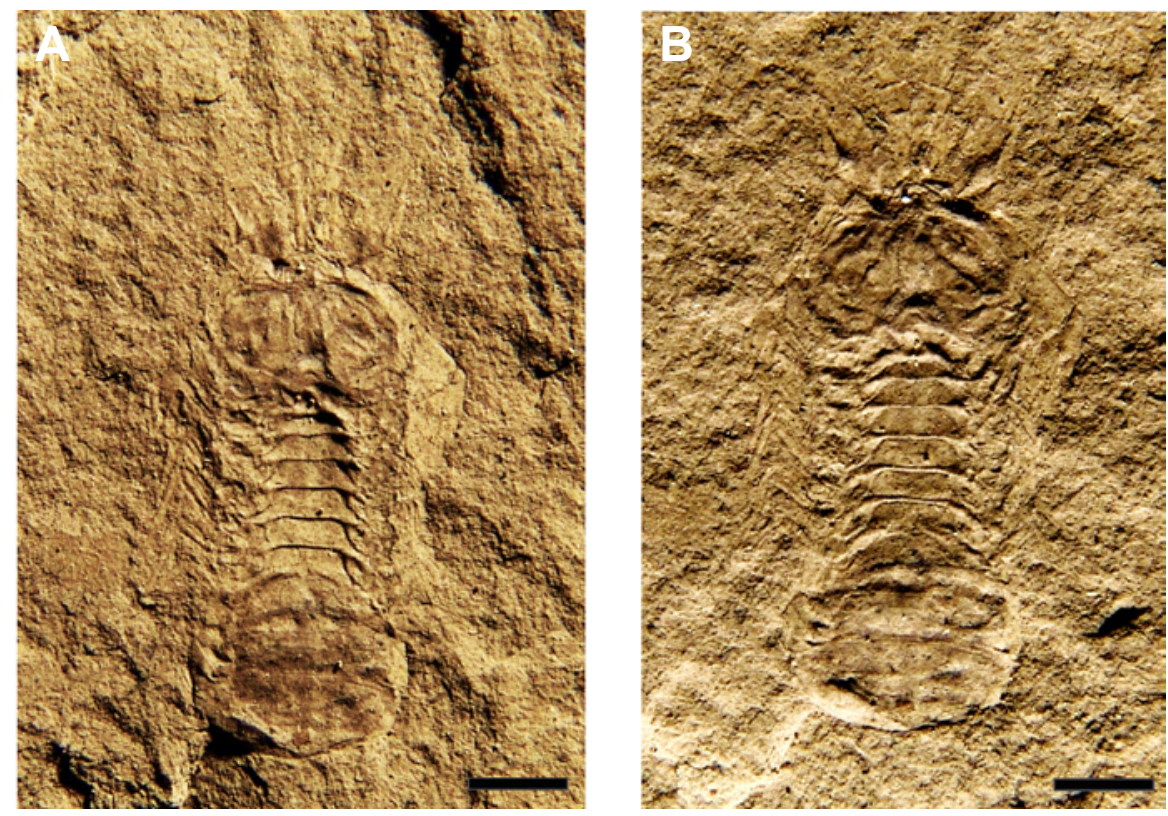

Figure 4. A-B, Photographs of Permocaris purperae gen. et sp. nov., UFRGS/MP-I-6643, holotype. Scale bars $=2 \mathrm{~mm}$. 
A

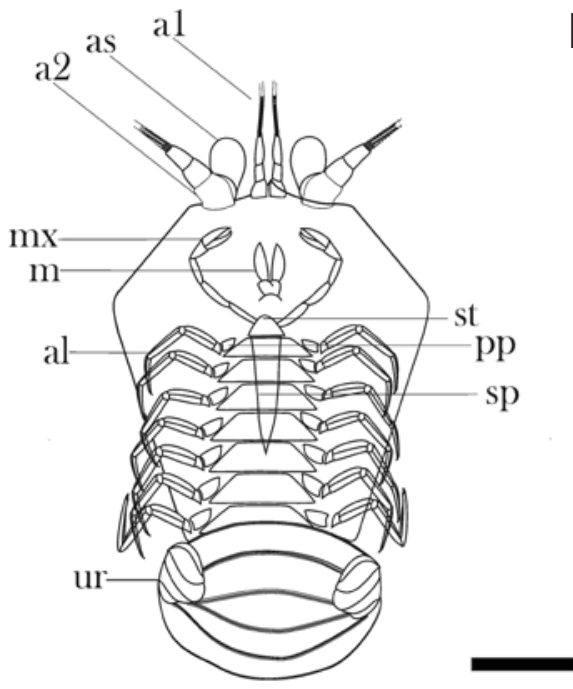

B

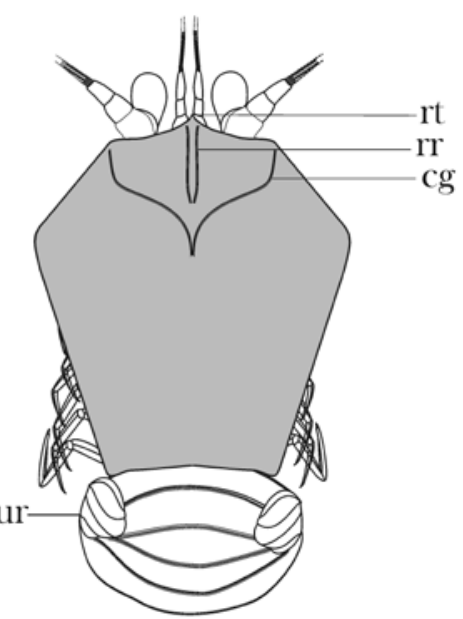

Figure 5. Reconstructions of Permocaris purperae gen. et sp. nov., in ventral view (A) and dorsal view (B). Reconstructions were based on camera lucida illustrations. Only the visible portion of the flagella was represented, as they are not completely preserved. Abbreviations: a1, antennae 1 (antennule); as, antennal scale; a2, antennae 2 (antennae); mx, maxilliped; m, mouth; al, ambulatory legs; ur, uropods; $\mathbf{r t}$, rostrum; rr, rostrum ridge; cg, cervical groove; st, sternite; pp, protopod; sp, sternal process. Scale bar = $2 \mathrm{~mm}$.

are five segments visible in the pleon, and fan-shaped molds lateral to the segments are probably uropods. The telson is not visible. Appendages: the antennule protopods have three joints, the proximal one being short and broad, the following short and slender, and the third one slender and longer than the first two. A long, simple multi-articulated flagellum of poor preservation is articulated to the third joint. The antennae are poorly preserved, though it is possible to distinguish the protopod with three joints: a short and broad proximal one, followed by two shorter and slender ones. Only a small portion of the simple multi-articulated flagellum is visible. On the outer side of the antennae, an oval-shaped structure as long as the protopod's three joints is observed, which we identified as the antennal scale, formed by the antennae exopod. Eyes are not present, although similar crustaceans present pedunculated eyes. There are eight pairs of thoracic appendages; the first pair appears to have a chelate distal joint, the upper part of the joint being slightly longer than the inferior, and is probably a chelate maxilliped. The following seven pairs of appendages are slender, biramous, and have similar lengths and widths. Four joints are visible and a longitudinal line seems to divide the limb in two, the endopod and exopod appearing to be fused. The seven pairs of thoracic appendages are ambulatory legs. At the pleon only lateral fan-shaped uropods are visible.

\section{Iraticaris gen. nov. Adami-Rodrigues \& Pazinato}

Type species. Iraticaris damianii. sp. nov. Adami-Rodrigues \& Pazinato.

Etymology. Irati Formation crustacean.

Diagnosis. As for the species.

Iraticaris damianii sp. nov. Adami-Rodrigues \& Pazinato (Figures 6-7)
Etymology. In honor of Dr. Irajá Damiani Pinto.

Holotype. UFRGS/MP-I-6646a,b (mold and countermold). Horizon and locality. Outcrop I, km 90 of the BR-290 (Porto Alegre-Uruguaiana way), Minas do Leão County, Rio Grande do Sul, Brazil and Outcrop III, Pantano Grande, RS, Brazil; lower Permian, Irati Formation.

Diagnosis. Round-shaped carapace, sub-oval, almost as wide as long, ventrally expanded comprising all cephalothorax and proximal portion of pleon; anterior margin concave with anterolateral spines and one pair of antennal spines; one pair of gastric spines; short triangular rostrum; eight sub-hexagonal sternites; last pair of thoracic legs highly developed; short pleon, about $1 / 7$ of cephalothorax's length, ventrally inflected. Description. The round-shaped carapace is $29 \mathrm{~mm}$ in length from the base of the rostrum and $24 \mathrm{~mm}$ wide, being almost as long as wide. The rostrum has the shape of an isosceles triangle, with a broader base $(2.7 \mathrm{~mm})$ than its height $(2.4$ $\mathrm{mm}$ ). From its apex, a mid-ridge extends back until the end of the anterior third of the carapace. The anterior margin is 13.5 $\mathrm{mm}$ long, concave between the rostrum and the outer limit of the carapace, which is ornamented with anterolateral spines, and relatively developed. Between the rostrum and the anterolateral spines there is a pair of antennal spines, which are slightly developed. The margins of the rostrum extend backwards in ridges that continue through the anterior third of the carapace, ending in a pair of gastric spines. Distinctive gastric ridges reach the posterior limit of the mid-ridge. Prominent hepatic lobes are located between the gastric ridges and the outer limit of the carapace, in its anterior third. The posterior margin is slightly concave, being almost as long as the anterior margin. The lateral margins are ventrally inflected. The thorax has eight sternites; the first one is triangular and the remaining hexagonal, in which the height gradually increases in the following order: $1.5 \mathrm{~mm}, 3.0 \mathrm{~mm}$, $3.75 \mathrm{~mm}, 4.5 \mathrm{~mm}$ and the last three $5.25 \mathrm{~mm}$; the latter is 

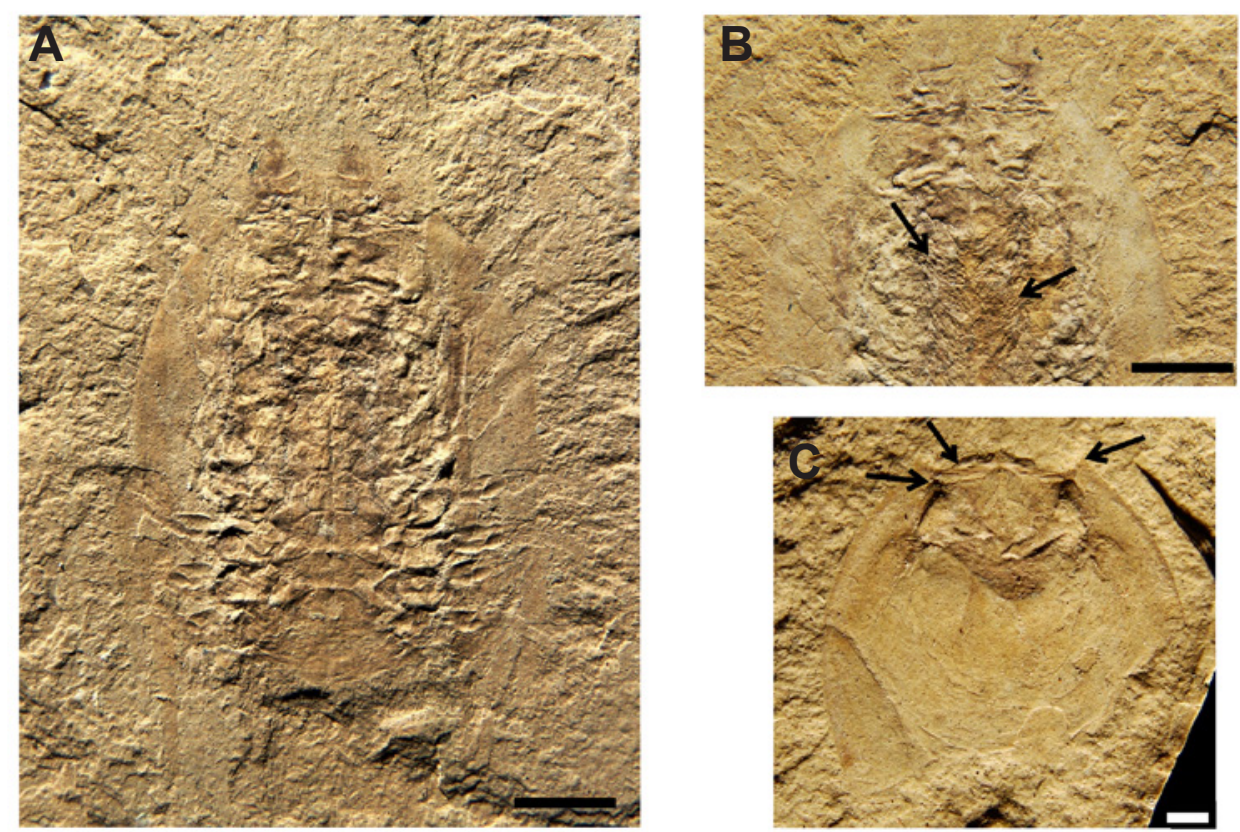

Figure 6. Photographs of Iraticaris damianii gen. et sp. nov. Adami-Rodrigues \& Pazinato. A, UFRGS/MP-I-6646a holotype (mold); B, anterior portion of cephalothorax, the black arrows indicate the branchial exopodites, UFRGS/MP-6646b (countermold); C, an external mold of an isolated carapace, notably round shaped. It is possible to notice one pair of anterolateral spines, antennal spines, gastric spines, the gastric ridges, and the branchiostegal development, as indicated by the arrows. Scale bars: $A, B=5 \mathrm{~mm} ; C=2 \mathrm{~mm}$.
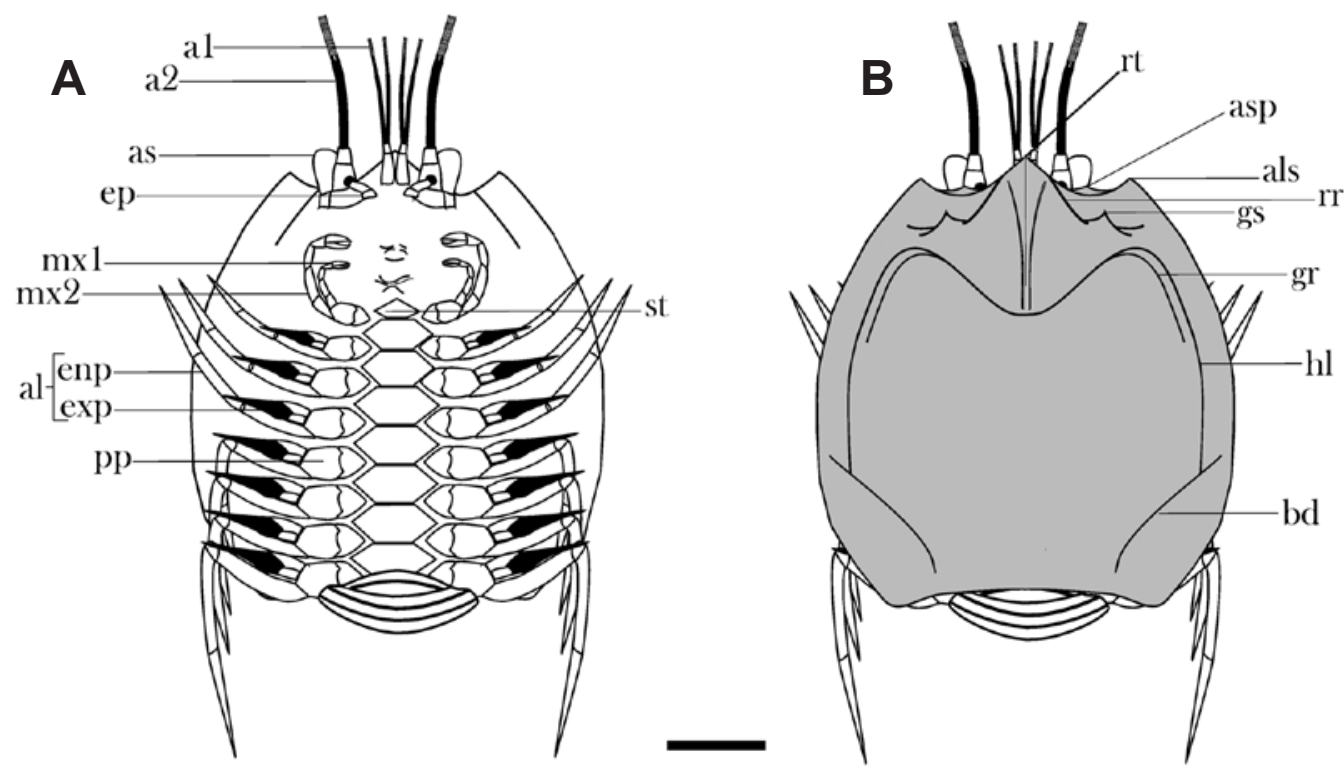

Figure 7. Reconstructions of Iraticaris damianii gen. et sp. nov. Adami-Rodrigues \& Pazinato. In the reconstructions, based on camera lucida illustrations, of the ventral view (A) and dorsal view (B), all the ambulatory legs are represented, based mostly in the last three pairs of better preservation. Abbreviations: a1, antennae 1 (antennule), as, antennae scale; a2, antennae 2 (antennae); ep, eye peduncule; mx1, maxilliped 1; mx2, maxilliped 2; al, ambulatory legs; end, endopod; exp, exopod; pp, protopod; rt, rostrum; asp, antennae spine; als, anterolateral spine; rr, rostrum ridge; gs, gastric spine; gr, gastric ridge; st, sternite; hl, hepatic lobe; db, branchiostegal development. Scale bar = $5 \mathrm{~mm}$.

covered by the impression of the pleon, preventing accurate measurement of the size. The pleon is ventrally inflected, being about $1 / 7$ of the total length of the crustacean, except the antennae. Five pleomeres are distinguished, the latter covering the last thoracic sternite. A telson and uropods are not visible. Appendages: the antennule protopods have two visible joints: a proximal longer and a distal shorter; there are biramous, multi-articulated flagella. The antennal protopods have three joints: the proximal one is short and broad, the second is longer, and the distal one shorter than the latter. The flagellum is simple and multi-articulated. Lateral to the antennae, oval antennae scales are present. The eyes are small and pedunculated. On the cephalothorax eight pairs of appendages are visible, the first two distinctively smaller 
than the remaining and with chelated extremities, possibly maxillipeds. In the next six pairs of appendages, three long and broad joints are visible. A lamellar exopod is present on the fifth appendage, which must have been lost in the remaining, the ambulatory legs being biramous. The last endopod is distinctively more developed than all the other ones, in which two broad joints are visible; the second one is curved in its distal portion, ending in a thin and pointed joint.

\section{Pittinucaris gen. nov.}

Type species. Pittinucaris wuerdigae sp. nov.

Etymology. Small crustacean.

Diagnosis. As for the species.

Pittinucaris wuerdigae sp. nov.

(Figures 8-9)

Etymology. In honor of Dra. Norma Würdig.

Holotype. UFRGS/MP-I-6644.

Horizon and locality. Outcrop II, Pantano Grande, RS, Brazil; lower Permian, Irati Formation.

Diagnosis. Carapace with distinct separation between cephalon and thorax; the anterior third being sub-rectangular and the remaining two thirds rounded; anterior margin straight, without spines; small triangular rostrum; mid-groove dividing the posterior two thirds of the carapace, delimiting the positions of the branchiostegites; seven trapezoidal sternites; ventrally inflected pleon.

Description. Small crustacean reaching a maximum length of $11 \mathrm{~mm}$. Carapace longer than wide, $8.2 \mathrm{~mm}$ long and 7.5 mm wide at its widest section (just above the cephalothorax joint). The anterior third of the carapace is sub-rectangular in shape, defining the cephalon, and the remaining two thirds are rounded, delimiting the thorax. The rostrum is short, narrow, and ridged, resembling an equilateral triangle $1.1 \mathrm{~mm}$ high.
The anterior margin is straight, $3 \mathrm{~mm}$ long, and without spines. The posterior margin is concave, and slightly shorter than the anterior margin. A mid-groove divides the thoracic portion in two, delimiting the branchiostegal chamber. There are seven trapezoidal sternites in the cephalothorax; from the first one a long triangular sternal process emerges, tapering towards the following sternites until it ends in a wedge at the beginning of the fifth sternite. The pleon is ventrally inflected; six somites and two lateral projections, probably the uropods, are visible. It is half of the carapace's width and less than $1 / 3$ of the total length of the crustacean. Appendages: antennule protopods show two joints, the proximal longer than the distal one; a simple multi-articulated flagellum is preserved. The antennal protopods exhibit only a proximal short and broad joint and a simple multi-articulated flagellum; lateral to this ramus lies an oval structure, possibly the antennae scale. Distinct eye globules are lateral to the rostrum. The thoracic appendages are poorly preserved and lost in most of the specimens. Only a slender pair of maxillipeds on the anterior portion of the cephalothorax and one pair of ambulatory legs is distinguished; the latter is biramous. The ventrally inflected pleon shows fan-like uropods on both sides.

\section{DISCUSSION}

\section{Taxonomic and systematic issues}

The crustaceans exhibit a great degree of diversity in form and they have benefited from the specialization of a large number of appendages (Schram, 1986). They have conquered the most diverse environments and habitats, having a successful evolutionary history, from probably the Cambrian all the way to the Recent (Schram, 1986; Martin \& Davis, 2001). Pygocephalomorphs represent among the crustaceans a morphological type that for some reason did not last long on the scale of geological time. Their peculiar morphology, a mysid-like cephalothorax and decapod-like pleon, has led to different phylogenetic interpretations.
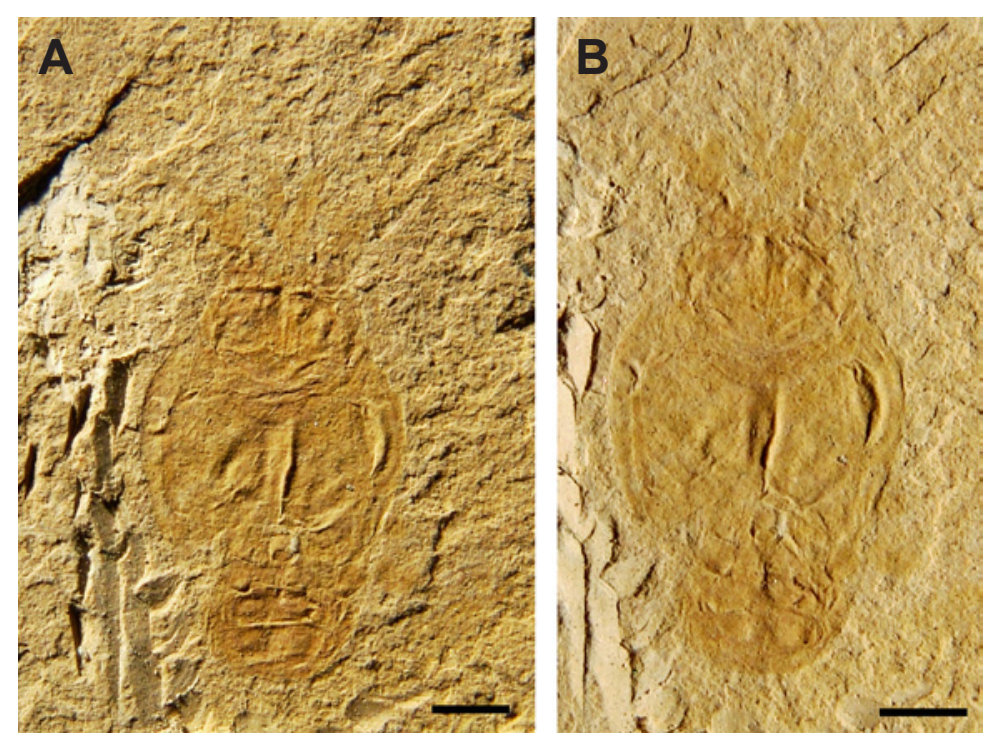

Figure 8. A-B, photographs of Pittinucaris wuerdigae gen. et sp. nov., UFRGS/ MP-I-6644, holotype. Scale bars $=2 \mathrm{~mm}$. 

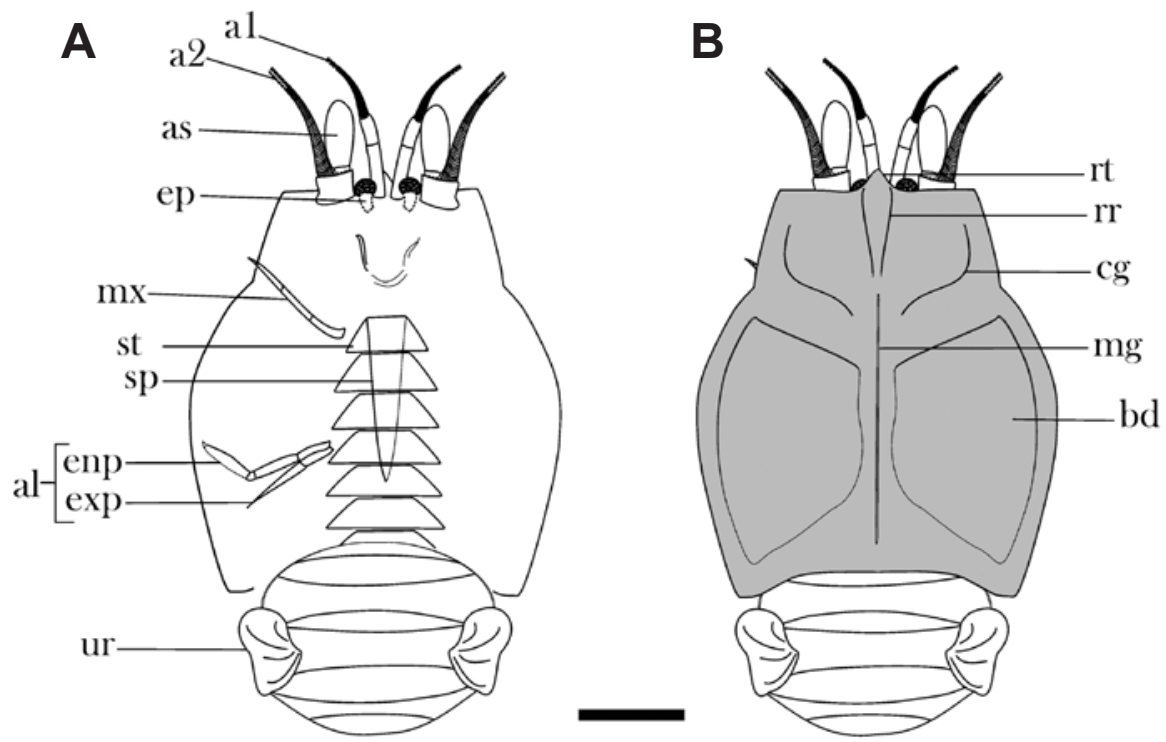

Figure 9. Reconstructions of Pittinucaris wuerdigae gen. et sp. nov. The reconstructions, of ventral view (A) and dorsal view (B), are based on camera lucida illustrations and only two of the ambulatory legs are represented. Abbreviations: a1, antennae 1 (antennule); a2, antennae 2 (antennae); as, antennae scale; ep, eye peduncule; $\mathbf{m x}$, maxilliped; st, sternite; sp, sternal process; al, ambulatory leg; end, endopod; exp, exopod; ur, uropod; rt, rostrum; rr, rostrum ridge; cg, cervical groove; $\mathbf{m g}$, mid-groove; bc, branchiostegal chamber. Scale bar = 2 mm.

Some studies consider the group as a less-derived ancestor of decapods (Beurlen, 1930; Brooks, 1969), owing to the higher number of ambulatory legs on the cephalothorax. Pygocephalomorphs have between seven and eight while decapods have a characteristic five pairs of legs. Others relate the group to mysids (Huxley, 1857; Schram, 1986), being currently positioned as a fossil order of the 'mysidaceans' (Schram, 1986; Taylor et al,. 1998), particularly based on the morphology of the carapace, the presence of oöstegites, and phylogenetic analyzes. The specialization of one or two pairs of ambulatory appendages into maxillipeds used for collecting and processing food, the presence of seven or eight pairs of ambulatory legs, and females carrying oöstegites are diagnostic features more likely to be recognized in fossils that support such a systematic positioning. However, the preservation of these characters depends on certain taphonomic conditions, and are not always found in specimens. It requires complete preservation of crustaceans in ventral or lateral views, but many of the pygocephalomorph taxa described are based on isolated carapaces (Beurlen, 1931; Schram, 1978; Shen, 1983; Jones et al., 2015). This fact might have led to overestimation of the number of species or led to the misinterpretation of certain taxa, positioning in the same group crustaceans that might not be directly related. A recent review of the genus Pygocephalus Huxley, 1857 exemplifies the problem by determining that one of the original figured specimens is the result of an assemblage of isolated pieces of two individuals, the carapace of one and the pleon of another, preserved in such a way to look like a single specimen (Pinto \& Würdig, 2014). The work also states that more than one species of malacostracan crustacean could be present in the same location, even in the same rock sample, as found in this study.
The pygocephalomorphs described herein differ from other genera described in the literature. Although Permocaris resembles Pygaspis, the former is apparently less than half the size of the latter. Pygaspis presents a papillose ornamented ovoid carapace (Pinto \& Adami-Rodrigues, 1996), while Permocaris has a non-ornamented kite-like carapace.

The same comparison could be made with respect to Notocaris Broom, 1931, recorded in the Whitehill Formation, Karoo Basin, South Africa, the stratigraphic equivalent to the Irati Formation. However, Notocaris's carapace has one pair of anterolateral spines and one or two pairs of lateral spines (Kensley, 1975). Furthermore, there is no holotype or lectotype for Notocaris (Broom, 1931; Kensley, 1975) and, as noted for some of the specimens used by Broom (1931), their reconstructions do not correspond to the actual characters of the fossils, requiring a revision of the genus.

Of all pygocephalomorph species in the literature, Iraticaris most resembles Anthrapalaemon grossarti Salter, 1861 from the Upper Carboniferous of England in its roundshaped carapace, but it differs by the presence of gastric spines and a ventrally inflected pleon, in $A$. grossarti the pleon is fully extended posteriorly. The presence of an extended or inflected pleon is the subject of deliberation in relation to the taxonomy of the group (Pinto, 1971; Pinto \& Adami-Rodrigues, 1996; Pinto \& Würdig, 2014).

The pleon can appear in three most common ways: fully extended posteriorly, with all somites, telson, and uropods exposed; partially inflected, with telson and uropods folded so that the dorsally visible portion of the pleon consists of all but the last two or only the last segment(s); and, finally, fully inflected, appearing to be tightly rolled up and exposing only the anterior-most somites and perhaps part of the uropods. The crustaceans described in this paper have fully inflected 
pleomeres, and Iraticaris's differs from the others in its reduced length and width akin to the carapace.

The ventral inflection of the pleon seems to represent an evolutionary trend within pygocephalomorphs. While Carboniferous taxa have rather extended or partially inflected pleons, Permian taxa preferably present fully inflected pleomeres. However, it difficult to evaluate, considering the current knowledge, if this feature is the actual morphology or if it is taphonomic bias.

Among the Paleozoic species, the carapace of Pittinucaris wuerdigae is very similar to that of Jerometichenoria grandis Schram, 1978, which is described from a pyritized carapace recovered from a drill core from the Irensky Formation, lower Permian, Russia. Both species have an apparent separation on the carapace between the cephalon and thorax, a longitudinal median groove separating the carapace into two portions, possibly delimiting the branchial chambers (Figure 10). The carapace of Pittinucaris specimens is more than twice the size of Jerometichenoria's and shows no significant variation in dimensions. We consider it appropriate to erect Pittinucaris as a new genus, since the description is based on several molds of complete crustaceans, presenting a set of characters that allows us to identify it. Further studies should be conducted to evaluate potential synonyms.

\section{Taphonomic aspects and paleoenvironment}

When dealing with the preservation of arthropod remains, one must consider the biostratinomic and diagenetic processes
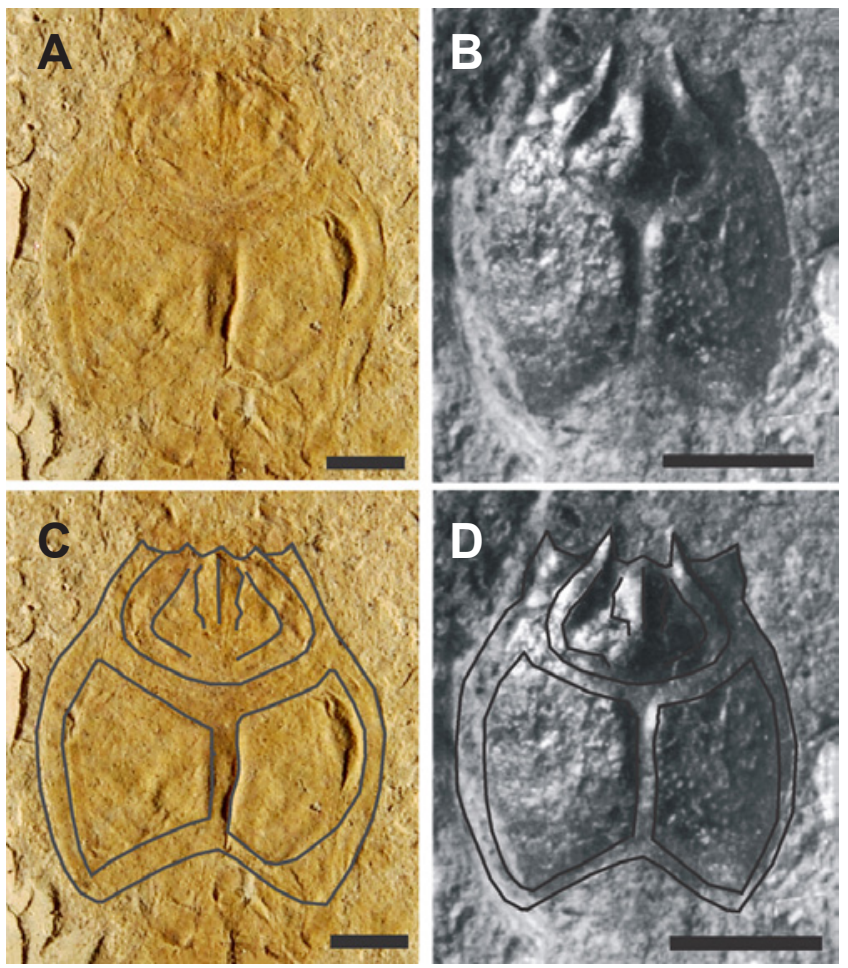

Figure 10. Comparison between Pittinucaris (A,C) and Jerometichenoria (B, D) carapaces. Russian specimen is tridimensional and pyritized while the Brazilian specimens are molds, which may obliterate diagnostic characters. Superimposed drawings highlight the similarities in shape and well-marked branchiostegal chambers. Scale bars: A,C = $1 \mathrm{~mm} ; \mathrm{B}, \mathrm{D}=$ based on Schram (1978). that could affect the chitin/calcified exoskeleton, among which we can emphasize transportation, predation, scavenging, bioturbation, bacterial degradation of the soft tissues, and chemical composition of the remains (Plotnick, 1986; AdamiRodrigues, 1998). Basic comparisons of the behavior of chitin versus calcified exoskeletons and the morphological and ecological conditions for potential preservation in different groups of arthropods have never been examined in detail (Mutel et al., 2008). However, it is known that the potential preservation of crustaceans is directly related to the amount of disturbance of the sediment by bioturbation (Plotnick, 1986), biological decomposition of the remains (Allison, 1986; Plotnick, 1986), and environmental conditions (Plotnick et al., 1988; Briggs \& Kear, 1994). Some special conditions or environments increase preservation potential, e.g. hypersalinity excludes scavengers and decay microbes allowing the cuticle and even soft tissue to be preserved (Krause et al., 2011; Piñeiro et al., 2012b). This is the case for recent records of exceptionally preserved pygocephalomorphs from the Mangrullo Formation in Uruguay (Piñeiro et al., 2012a,b).

The crustacean molds preserved in the silty shales described herein are fully articulated individuals, corresponding to the "tipo 1" of Pygocephalomorpha preservation of Matos et al. (2013). This kind of preservation probably indicates fast burial, within hours or a few days, of living or newly dead individuals (Matos et al., 2013). The burial, in this case, would not have been instant, but within a few hours. There are no signs of compression and almost all individuals are fossilized with the ventral side up, a stable hydrodynamic position after death (Adami-Rodrigues, 1998). Higher hydrostatic pressures reduce the effect of decay gasses in small invertebrates, which can prevent the carcasses from floating to the surface, but they remain floating at the water-sediment interface, where minimal bottom currents can move the carcasses around (Allison, 1986); this appears to be the case for the findings discussed here.

The decomposition of chitinous parts and soft tissues probably happened after burial, under anoxic conditions, preserving most of the individuals as fully articulated. According to Plotnick et al. (1988), the absence or inhibition of bioturbation, as under anoxic bottom waters or deep within the sediment, may be a necessary condition for the preservation of articulated arthropods. Crustacean carcasses do not stay articulated for very long once exposed at the water-sediment interface; generally only highly mineralized parts, such as decapod claws, remain intact after a few months of exposure (Stempien, 2005; Mutel et al., 2008; Krause et al., 2011), and pygocephalomorphs probably had slightly biomineralized carapaces (Matos et al., 2013). Bacteria and fungi are primarily responsible for the degradation of chitin and calcified proteins, the main materials of the cuticle of arthropods, in aquatic environments (Plotnick, 1986; Briggs \& Kear, 1994). It has been suggested that almost all degradation of chitin takes place in the upper aerobic layers, occurring much faster than in the bottom anoxic layers (Plotnick, 1986), since most of these chitin- 
decomposing bacteria are aerobic, found in marine water sediments and in the gut of arthropods (Plotnick, 1986; Adami-Rodrigues, 1998). Although, some experimental studies under laboratory conditions have shown that the rate of decay is not strongly influenced by the availability of oxygen (Allison, 1988; Briggs \& Kear, 1994).

The crustaceans described herein agree with the suggestion of Matos et al. (2013) that fully articulated pygocephalomorph records occur preferably in shale facies in the Irati Formation. The authors related this model of preservation to low-energy environments with a sudden increase in deposition of fine material, on anoxic bottom sediments, below storm-wave base in outer ramps. Perhaps a suddenly increase in rate of sedimentation and, therefore, possible development of anoxic conditions, may have been involved in the death of these pygocephalomorphs. This is suggested by the size variations in the crustaceans from outcrop I, where we collected several individuals of Permocaris and Iraticaris together from different size classes, indicative of the presence of juveniles and adults in this non-selective taphocoenosis.

The crustaceans from outcrop I are the first record of different genera of pygocephalomorphs occurring together in the Paraná Basin. Usually, sites occur with abundant individuals of the same species or genus, e.g. Liocaris, Paulocaris, and the crustaceans described herein are found in limestone and shale facies of the Irati Formation while Pygaspis occurs only in siliciclastic shale, possibly indicating some environmental control on species distribution. The morphology of Pygocephalomorpha indicates that they were benthic crustaceans (Schram, 1986), but it does not provide evidence of the type of paleoenvironment they lived in. Normally they are found in association with fossil taxa that are not diagnostic of freshwater nor of marine environments, so pygocephalomorphs are typically interpreted as inhabitants of brackish environments (Schram, 1981). The fossil assemblage from the outcrops in this study also does not provide fossils diagnostic of a specific environment, but the presence of insect remains and plants suggests that it could be a freshwater body, or at least be in proximity to one. A long discussion on what the paleoenvironment of the Irati Formation was is not the aim of this study; however, the authors suggest a hypothesis to be considered in future work, indicated by the endemic pattern of Pygocephalomorpha to date. It is considered that the evolution of these crustaceans might have been restricted to a system of small isolated ponds that, when joined from time to time, would provide a mode of dispersion for species over a larger distance within the basin (Adami-Rodrigues, 1998).

\section{CONCLUSIONS}

Description of new taxa of Pygocephalomorpha in the Paraná Basin, Southern Brazil, extends the knowledge about this group in Gondwana. Permocaris purperae gen. et sp. nov., Iraticaris damianii gen. et sp. nov. Adami-Rodrigues $\&$ Pazinato and Pittinucaris wuerdigae gen. et sp. nov. come from different outcrops of similar lithology, a siltic shale belonging to the Irati Formation. Permocaris purperae gen. et sp. nov. and Iraticaris damianii gen. et sp. nov. AdamiRodrigues \& Pazinato occur in association in outcrop I.

There is still a lot to be done concerning pygocephalomorph phylogeny, dispersal of species, and possible correlations in distant basins. Description of new taxa should be based on complete specimens to avoid mistakes that can overestimate taxon numbers. A deeper analysis of possible relationships between Pittinucaris and Jerometichenoria Schram, 1978 must be performed, as well as the relationships between these new taxa and the remaining taxa of the Paraná Basin, seeking a reconstruction of the evolutionary history of pygocephalomorphs.

\section{ACKNOWLEDGMENTS}

The authors thank R.R. Davies for critically reading the manuscript, F.R. Schram and an anonymous reviewer for their helpful comments and suggestions for improving the manuscript.

\section{REFERENCES}

Adami-Rodrigues, K. 1998. Crustáceos permianos da faixa Minas do Leão - Pantano Grande, RS e sua posição estratigráfica. Programa de Pós-Graduação em Geociências, Universidade Federal do Rio Grande do Sul, M.Sc. thesis, 61 p.

Adami-Rodrigues, K. \& Pinto, I.D. 2000. Os Crustáceos Ordem Pygocephalomorpha. In: M. Holz \& F. De Ros (eds.) Paleontologia do Rio Grande do Sul, CIGO/UFRGS, p. 141-147.

Allison, P.A. 1986. Soft-bodied animals in the fossil record: The role of decay in fragmentation during transport. Geology, 14:979-981.

Allison, P.A. 1988. The role of anoxia in the decay and mineralization of proteinaceous macro-fossils. Paleobiology, 14:139-154. doi:10.1017/S009483730001188X

Beurlen, K. 1930. Vergleichende Stammesgeschichte Grundlagen, Methoden, Probleme unter besonderer Berüksichtigung der höheren Krebse. Fortschritte der Geologie und Palaeontologie, 8:317-586.

Beurlen, K. 1931. Crustaceenrest der Mesosaurierschichten (Unterperm) von Brasilien (São Paulo). Paläontologische Zeitschrift, 1:35-50.

Beurlen, K. 1934. Die Pygaspiden, eine neue Crustaceen(Entomostraceen)-Gruppe aus den Mesosaaurier führenden Iraty-Schichten Brasiliens. Paläontologische Zeitschrift, 19:122-138.

Beurlen, K. 1953. O gênero Paulocaris Clarke nas camadas do Brasil meridional. Rio de Janeiro, Departamento Nacional de Produção Mineral, Divisão de Geologia e Mineralogia, 8 p. (Boletim 65).

Briggs, D.E.G. \& Kear, A.J. 1994. Decay and mineralization of shrimps. 9:431-456. doi:10.2307/3515135

Brooks, H.K. 1962. The Paleozoic Eumalacostraca of North America. Bulletins of American Paleontology, 44:163-335.

Brooks, H.K. 1969. Eocarida In: R.C. Moore (ed.) Treatise on Invertebrate Paleontology. Part R, Arthropoda 4, Russel Rutter Company, p. 332-345.

Broom, R. 1931. On the Pygocephalus-like Crustacean of the South African Dwyka. Proceedings of the Zoological Society of London, 101:571-573. 
Clarke, J.M. 1920. New Paleozoic Crustaceans II. Crustacea from the Permian of São Paulo, Brazil. New York State Museum Bulletin, 219/220:135-137.

Fabre, J. \& Huard, D. 1967. Un arthropode nouveau des Upper Dwyka Shales Pygaspis ginsburgi, nov. sp. Annales de Paleontologie. 53:121-147.

Figueiredo, P.M. 1972. A faciologia do Grupo Passa Dois no Estado do Rio Grande do Sul. Revista Brasileira de Geociências, 2:216-235.

Holz, M.; França, A.B.; Souza, P.A.; Iannuzzi, R. \& Rohn, R. 2010. A stratigraphic chart of the Late Carboniferous/Permian succession of the eastern border of the Paraná Basin, Brazil, South America. Journal of South American Earth Sciences, 29:381-399. doi:10.1016/j.jsames.2009.04.004

Hotton III, N.; Feldmann, R.M.; Hook, R.W. \& Dimichele, W.A. 2002. Crustacean-bearing continental deposits in the Petrolia Formation (Leonardian Series, Lower Permian) of North-Central Texas. Journal of Paleontology, 76:486-494. doi:10.1666/00223360(2002)076<0486:CBCDIT>2.0.CO;2

Huxley, T.H. 1857. Description of a new crustacean Pygocephalus cooperi, from the Coal Measures. Quarterly Journal of Geological Society, 13:363-369.

Irham, M.; Schram, F.R. \& Vonk, R. 2010. A new species of Pygocephalomorpha (Eumalacostraca, Peracarida) from the Leitchfield Formation, Lower Carboniferous (Mississippian) of Grayson County, Kentucky, U. S. A. In: C.H.J.M. Fransen; S. De Grave \& P.K.L. Ng (eds.) Studies on Malacostraca, Brill, p. 343-355.

Jones, W.T.; Feldmann, R.M.; Schweitzer, C.E.; Reitano, A. \& Insacco, G. 2015. New pygocephalomorph (Peracarida) from the Permian of the Sosio Valley (Sicily, Italy). Journal of Crustacean Biology, 35:627-632. doi:10.1163/1937240X-00002367

Kensley, B. 1975. Taxonomic status of the pygocephalomorphic Crustacea from the Dwyka 'White Band' (Permo-Carboniferous) of South Africa. Annals of the South African Museum, 67:25-33.

Krause, R.A.; Parsons-Hubbard, K. \& Walker, S.E. 2011. Experimental taphonomy of a decapod crustacean: Long-term data and their implications. Palaeogeography, Palaeoclimatology, Palaeoecology, 312:350-362. doi:10.1016/j.palaeo.2011.03.020

Machado, E.R. \& Castanho, O.S. 1956. Pesquisa de carvão mineral na faixa sedimentar do Rio Grande do Sul. Porto Alegre, Departamento Autônomo de Carvão Mineral, Secretaria de Obras do Estado do Rio Grande do Sul, 42 p.

Martin, J.W. \& Davis, G.E. 2001. An updated classification of the recent Crustacea. Natural History Museum of Los Angeles County - Science Series, 39:1-124. doi:10.1086/345208

Matos, S.A.; Pretto, F.A. \& Simões, M.G. 2013. Tafonomia dos Pygocephalomorpha (Crustacea, Peracarida, Malacostraca), Permiano, Bacia do Paraná, Brasil, e seu significado paleoambiental. Revista Brasileira de Paleontologia, 16:97-114. doi:10.4072/rbp.2013.1.08

Mezzalira, S. 1954. Novas ocorrências de crustáceos fósseis da Formação Irati do sul do Brasil. In: F.W. Lange (ed.) Paleontologia do Paraná, Comissão de Comemoração do Centenário do Paraná, p. 163-173.

Mutel, M.H.E.; Waugh, D.A.; Feldmann, R.M. \& Parsons-Hubbard, K.M. 2008. Experimental taphonomy of Callinectes sapidus and cuticular controls on preservation. 23:615-623. doi:10.2110/ palo.2008.p08-024r

Peach, B.N. 1883. Further researches among the Crustacea and Arachnida of the Carboniferous rocks of the Scottish Border. Proceedings of the Royal Society of Edinburgh, 30:511-529.
Piñeiro, G.; Morosi, E.; Ramos, A. \& Scarabino, F. 2012a. Pygocephalomorph crustaceans from the Early Permian of Uruguay: Constraints on taxonomy. Revista Brasileira de Paleontologia, 15:33-48. doi:10.4072/rbp.2012.1.03

Piñeiro, G.; Ramos, A.; Morosi, E.; Goso, C.; Scarabino, F. \& Laurin, M. 2012b. Unusual environmental conditions preserve a Permian mesosaur-bearing Konservat-Lagerstätte from Uruguay. Acta Palaeontologica Polonica, 57:299-318. doi:10.4202/ app. 2010.0113

Pinto, I.D. 1955. Descoberta de fósseis na Formação Palermo no Rio Grande do Sul. Boletim do Instituto de Ciências Naturais, 2:19-23.

Pinto, I.D. 1971. Reconstituição de Pygaspis Beurlen, 1934 (Crustacea-Pygocephalomorpha). Sua posição sistemática, seu significado e de outros fósseis para o Gondwana. Anais da Academia Brasileira de Ciências, 43:387-401.

Pinto, I.D. 1972. Late Paleozoic insects and crustaceans from Paraná Basin and their bearing on chronology and continental drift. Anais da Academia Brasileira de Ciências, 44:247-254.

Pinto, I.D. \& Adami-Rodrigues, K. 1996. Pygocephalomorph Crustacea. New data and interpretations, with emphasis on Brazilian and South African forms. Pesquisas, 23:41-50.

Pinto, I.D. \& Würdig, N L. 2014. Contribution to the knowledge of the genus Pygocephalus Huxley, 1857: morphology and taxonomy. Revista Brasileira de Paleontologia, 17:275-288. doi:10.4072/rbp.2014.3.01

Plotnick, R.E. 1986. Taphonomy of a modern shrimp: implications for the arthropod fossil record. 1:286-293. doi:10.2307/3514691

Plotnick, R.E.; Baumiller, T. \& Wetmore, K.L. 1988. Fossilization potential of mud crab, Panopeus (Brachyura: Xanthidae) and temporal variability in crustacean taphonomy. Palaeogeography, Palaeoclimatology, Palaeoecology, 63:27-43. doi:10.1016/00310182(88)90089-2

Prestwich, J. 1840. On the geology of the Coalbrookdale. Transactions of the Geological Society of London, 5:413-495.

Rogers, A.W. \& Du Toit, A.L. 1909. The Karoo System. In: A.W. Rogers \& A.L. Du Toit (eds.) An introduction to the geology of Cape Colony, Longmans Green \& Co., p. 166-233.

Salter, J.W. 1861. On some higher Crustacea of the British Coal Measures. Quarterly Journal of Geological Society, 17:528-533.

Salter, J.W. 1863. On some fossil Crustacea from the Coal-Measures and Devonian rocks of British North America. Quarterly Journal of Geological Society, 19:75-80.

Schram, F.R. 1974. Peracarida of North America. Fieldiana: Geology, 33:95-124.

Schram, F.R. 1978. Jerometichenoria grandis n. gen., n. sp. (Crustacea: Mysidacea) from the Lower Permian of the Soviet Union. Journal of Paleontology, 52:605-607.

Schram, F.R. 1981. Late Paleozoic crustacean communities. Journal of Paleontology, 55:126-137.

Schram, F.R. 1984. Relationships within Eumalacostracan Crustacea. Transactions of the San Diego Society of Natural History, 20:301-312. doi:10.5962/bhl.part.29008

Schram, F.R. 1986. Crustacea. New York, Oxford University Press, $606 \mathrm{p}$.

Schram, F.R. 1988. Pseudotealliocaris palinscari n. sp., a pygocephalomorph from the Pocono Formation, Mississippian of Pennsylvania. Transactions of the San Diego Society of Natural History, 21:221-225.

Shen, Y.B. 1983. A new pygocephalomorph genus (Eumalacostraca) of Lower Carboniferous from Anhui. Acta Palaeontologica Sinica, 22:663-668. 
Stempien, J.A. 2005. Brachyuran Taphonomy in a Modern TidalFlat Environment: Preservation Potential and Anatomical Bias. 20:400-410. doi:10.2110/palo.2004.p04-40

Taylor, R.S.; Shen Y.B. \& Schram, F.R. 1998. New Pygocephalomorph crustaceans from the Permian of China and their phylogenetic relationships. Palaeontology, 41:815-834.

Vieira, P.C.; Mezzalira, S. \& Ferreira, F.J.F. 1991. Mesossaurídeo (Stereosternum tumidum) e crustáceo (Liocaris huenei) no
Membro Assistência da Formação Irati (P) nos municípios de Jataí e Montevidiu, Estado de Goiás. Revista Brasileira de Geociências, 21:224-235.

Received in February, 2016; accepted in September, 2016. 